Revta brasil. Bot., São Paulo, V.23, n.1, p.69-76, mar. 2000

\title{
Multiple forms of cotyledonary $\beta$-galactosidases from Vigna unguiculata quiescent seeds
}

\author{
JOAQUIM ENÉAS-FILHO ${ }^{1,2}$, FABRÍCIO BONFIM SUDÉRIO ${ }^{1}$, ENÉAS GOMES-FILHO ${ }^{1}$ \\ and JOSÉ TARQUÍNIO PRISCO ${ }^{1}$
}

(received: June 6, 1999; accepted: November 22, 1999)

\begin{abstract}
Multiple forms of cotyledonary $\beta$-galactosidases from Vigna unguiculata quiescent seeds). Cotyledonary $\beta$-galactosidases were isolated and partially purified from Pitiúba cowpea (Vigna unguiculata (L.) Walp.) quiescent seeds. The purification steps consisted of precipitation of the crude extract with ammonium sulphate in the range of 20-60\% saturation, acid precipitation, DEAE-Sephadex ion-exchange chromatography and Lactosyl-Sepharose affinity chromatography. This purification process gave rise to three $\beta$-galactosidases-rich fractions: $\beta$-gal I, $\beta$-gal II and $\beta$-gal III, which were purified about 5, 509, and 62 fold, respectively. They reached maximal enzyme activity at different $\mathrm{pH}$ ranges: 3.5-4.5 for $\beta$-gal I, 3.0-3.5 for $\beta$-gal II, and 3.0-4.0 for $\beta$-gal III. Their maximal activities were reached when the temperature of the assay medium was $60^{\circ} \mathrm{C}$, and preincubation of the enzymes at different temperatures has shown that they were heat-stable up to $50^{\circ} \mathrm{C}$. There were no significant differences among the partially purified enzymes as to their response to the different effectors tested, except for $\mathrm{Mn}^{2+}$ and EDTA, which affected $\beta$-gal I, $\beta$-gal II, and $\beta$-gal III differently. They were slightly affected by $\mathrm{Mg}^{2+}, \mathrm{Ca}^{2+}, \mathrm{Zn}^{2+}, \mathrm{Co}^{2+}$, tartarate, molybdate, glucose, and lactose, strongly inhibited by $\mathrm{Cu}^{2+}$ and galactose, and inactivated by $\mathrm{Hg}^{2+}$. These chemical and physical properties are similar to those found for other plant $\beta$-galactosidases. Although three isoforms of this enzyme were obtained through this purification process, isoelectric focusing in polyacrylamide slab gel of these enzyme-proteins suggests that cotyledons of Pitiúba cowpea quiescent seeds possess four isoforms of $\beta$-galactosidases.
\end{abstract}

RESUMO - (Múltiplas formas de $\beta$-galactosidases cotiledonares de sementes quiescentes de Vigna unguiculata). $\beta$-galactosidases cotiledonárias foram isoladas e purificadas, parcialmente, de sementes quiescentes de feijão-de-corda (Vigna unguiculata (L.) Walp.) Pitiúba. As etapas de purificação consistiram de precipitação do extrato bruto com sulfato de amônio na faixa de 20-60\% de saturação, precipitação ácida, cromatografia de troca-iônica em DEAE-Sephadex e cromatografia de afinidade em Lactosil- Sepharose. Esse processo de purificação deu origem a três frações ricas em $\beta$-galactosidases: $\beta$-gal I, $\beta$-gal II e $\beta$-gal III, as quais foram purificadas cerca de 5, 509 e 62 vezes, respectivamente. Elas atingiram máxima atividade enzimática em diferentes faixas de $\mathrm{pH}$ : 3,5-4,5 para $\beta$-gal I, 3,0-3,5 para $\beta$-gal II e 3,0-4,0 para $\beta$-gal III. Suas atividades máximas foram alcançadas quando a temperatura do meio de ensaio era $60^{\circ} \mathrm{C}$, e a preincubação das enzimas em diferentes temperaturas mostrou que elas eram termoestáveis até $50{ }^{\circ} \mathrm{C}$. Não houve diferenças significativas entre as enzimas parcialmente purificadas no que respeita à resposta dos diferentes efetores testados, exceto para $\mathrm{Mn}^{2+}$ e EDTA, que afetaram, diferentemente, $\beta$-gal I, $\beta$-gal II e $\beta$-gal III. Elas foram ligeiramente afetadas por $\mathrm{Mg}^{2+}, \mathrm{Ca}^{2+}, \mathrm{Zn}^{2+}, \mathrm{Co}^{2+}$, tartarato, molibdato, glicose e lactose, fortemente inibidas por $\mathrm{Cu}^{2+} \mathrm{e}$ galactose, e inativadas por $\mathrm{Hg}^{2+}$. Essas propriedades químicas e físicas são semelhantes às encontradas para outras $\beta$-galactosidases de plantas. Embora três isoformas dessa enzima tenham sido obtidas através desse processo de purificação, a focalização isoelétrica em placa de gel de poliacrilamida dessas proteinas enzimáticas sugere que cotilédones de sementes quiescentes de feijão-de-corda Pitiúba possuem quatro isoformas de $\beta$-galactosidases.

Key words - Cotyledons, cowpea, enzyme purification, quiescent seeds

\section{Introduction}

1. Laboratório de Fisiologia Vegetal, Departamento de Bioquímica e Biologia Molecular, Centro de Ciências, Universidade Federal do Ceará. Caixa Postal 1065, 60001-970 Fortaleza, CE, Brasil.

2. Corresponding author. Rua Coronel Linhares, 280 Apto. 901, Meireles, 60170-240 Fortaleza, CE, Brasil, e-mail: joaquime@ufc.br. $\beta$-galactosidases (EC 3.2.1.23) are hydrolytic enzymes acting at $\beta$-galactosydic bonds of both oligo- and polysaccharides. Although they are widely distributed in plants (Wallenfels \& Malhotra 1961) their physiological role is still not well understood (Li et al. 1975, Matheson \& Saini 1977, 
70J. Enéas-Filho et al.: $\beta$-galactosidases from Vigna unguiculata seeds

Sekimata et al. 1989, Simos et al. 1989, Kundu et al. 1990, Giannakouros et al. 1991, Enéas-Filho et al. 1995). It has been suggested that these enzymes are associated to the depletion of oligo- and polysaccharides during the initial phases of seed germination (Matheson \& Saini 1977, Corchete \& Guerra 1986, Biswas 1987, Enéas-Filho et al. 1995), involved in the metabolism of cell wall constituints (Corchete \& Guerra 1987a, Edwards et al. 1988, Dopico et al. 1989, Konno \& Katoh 1992, Konno \& Tsumuki 1993, Gómez et al. 1995, Kitagawa et al. 1995), and in the process of fruit ripening (Pressey 1983, Ogawa et al. 1990, Veau et al. 1993, Ali et al. 1995). $\beta$-galactosidase activity has been detected in quiescent seeds (Dey 1984) as well as during germination and seedling establishment (Agrawal \& Bahl 1968, Corchete \& Guerra 1987b, Kundu et al. 1990, Buckeridge \& Reid 1994, Enéas-Filho et al. 1995). Isolation and purification studies suggest that they occur under multiple forms (Biswas 1986, 1987, Corchete \& Guerra 1987a, Kundu et al. 1990). However, it is not clear if these multiple forms come from the same part or organ of the seed or seedling or if each one of them come from a different parts of the seed or seedling. This knowledge is of fundamental importance for the study of their physiological role. Therefore, the objective of the present work was to isolate, partially purify, and characterize cotyledonary $\beta$-galactosidases extracted from quiescent Pitiúba cowpea seeds.

\section{Material and methods}

Pitiúba cowpea (Vigna unguiculata (L.) Walp.) seeds were obtained from the Centro de Ciências Agrárias, Universidade Federal do Ceará, Fortaleza, Ceará, Brazil. All seeds were stored in sealed glass bottles containing silica gel and kept at approximately $10{ }^{\circ} \mathrm{C}$ until used in the experiments.

The extraction of $\beta$-galactosidases was performed according to Corchete \& Guerra (1987b) with small modifications. Cotyledons of quiescent seeds were macerated and homogenized in cold $25 \mathrm{mM}$ citrate $-50 \mathrm{mM}$ phosphate buffer (McIlvaine 1921), pH 5.5, for 1h. The proportion of tissue to grinding medium (McIlvaine buffer) was 1:10 (m/v). All procedures were performed at $4{ }^{\circ} \mathrm{C}$ unless otherwise stated. The suspension was filtered through a nylon net, centrifuged at $10,000 \mathrm{~g}$ for $30 \mathrm{~min}$, and the precipitate discarded. The supernatant (crude extract) was precipitated with ammonium sulphate in the range of $20-60 \%$ saturation. After centrifugation, the precipitate was resuspended in McIlvaine buffer, $\mathrm{pH} 5.5$ and then lowered to 3.5 with gradual additions of $1 \mathrm{M}$ citric acid. This new precipitate was discarded after centrifugation at $10,000 \mathrm{~g}$ for $30 \mathrm{~min}$, and the $\mathrm{pH}$ of the supernatant was adjusted to 5.5 with $0.8 \mathrm{M}$ dibasic sodium phosphate, dialyzed against distilled water at $8{ }^{\circ} \mathrm{C}$ for $24 \mathrm{~h}$, and lyophilized $\left(\mathrm{F}_{20-60}\right)$ for further use. This lyophilized powder was resuspended in $25 \mathrm{mM}$ Tris - $\mathrm{HCl}$ buffer, $\mathrm{pH} 7.2$ and applied on a DEAE-Sephadex A-50 ion-exchange column $(17 \times 180 \mathrm{~mm})$ equilibrated with the same buffer at 10 ${ }^{\circ} \mathrm{C}$, and the flow rate adjusted to $31.5 \mathrm{~mL} \cdot \mathrm{h}^{-1}$. The automatic fraction collector was adjusted to collect fractions of $4.2 \mathrm{~mL}$ per tube, and the column was eluted with the equilibrium buffer. The retained peak was eluted with a linear $\mathrm{NaCl}$ gradient $(0.2$ to $1.0 \mathrm{M})$. Absorbance at $280 \mathrm{~nm}$ and $\beta$-galactosidase activity were determined in each fraction, and the ones that showed the highest activities (peaks DS-I and DS-II) were dialyzed against distilled water for $24 \mathrm{~h}$, concentrated and applied on a Lactosyl-Sepharose affinity column (16 x $190 \mathrm{~mm}$ ) equilibrated with McIlvaine buffer, $\mathrm{pH} 4.0$, diluted 1:4, containing $0.1 \mathrm{mM}$ EDTA and $1.0 \mathrm{mM}$ 2-ME at $4{ }^{\circ} \mathrm{C}$ (Campillo \& Shannon 1982). The flow rate was adjusted to $36 \mathrm{~mL} . \mathrm{h}^{-1}$; fractions of $4.8 \mathrm{~mL}$ were eluted with the equilibrium buffer and the retained fractions were eluted with the same buffer containing $100 \mathrm{mM}$ lactose and $0.5 \mathrm{M} \mathrm{NaCl}$. After each chromatography the column was regenerated with $6 \mathrm{M}$ urea (Simos et al. 1989).

$\beta$-Galactosidase activity was measured according to Kanfer et al. (1973) as modified by Enéas-Filho et al. (1995). A $3 \mathrm{mM}$ solution of the substrate was prepared by dissolving $\mathrm{p}$-nitrophenyl $\beta$-D-galactopyranoside (Sigma Co.) in McIlvaine buffer, $\mathrm{pH}$ 4.0. A $0.5 \mathrm{~mL}$ aliquot of this substrate solution was added to $0.5 \mathrm{~mL}$ of appropriately diluted enzyme extract, and the mixture was incubated at 37 ${ }^{\circ} \mathrm{C}$ for $15 \mathrm{~min}$. The reaction was stopped by the addition of $1.5 \mathrm{~mL}$ of $0.1 \mathrm{M} \mathrm{Na}_{2} \mathrm{CO}_{3}$. Enzyme activity was determined by measuring absorbance at $400 \mathrm{~nm}(\Delta \mathrm{A} 400)$ and subtracting this value from $\mathrm{A} 400$ of the blank. It was also expressed in units of activity (UA), one UA being defined as a difference in absorbance $(\Delta \mathrm{A} 400)$ of 0.01 (Enéas-Filho et al. 1995). Protein was determined by absorbance at $280 \mathrm{~nm}$ or according to Bradford (1976), using bovine serum albumin $2 \mathrm{x}$ crystalline (Sigma Co.) as standard.

To study the effect of the $\mathrm{pH}$ on enzyme activity the enzyme was assayed in Mcllvaine buffer in a $\mathrm{pH}$ range from 2.0 to 7.5. The effect of the assay temperature on enzyme activity was determined in the range from 30 to 80 ${ }^{\circ} \mathrm{C}$. Thermostability was studied taking $0.5 \mathrm{~mL}$ aliquots of the enzyme dissolved in McIlvaine buffer, $\mathrm{pH} 4.0$, preincubating this mixture for $10 \mathrm{~min}$ at temperatures ranging from 30 to $80^{\circ} \mathrm{C}$, and then cooling it and assaying 
Revta brasil. Bot., São Paulo, V.23, n.1, p.69-76, mar. 200071

for $\beta$-galactosidase. The effects of EDTA, galactose, glucose, lactose, tartarate, molybdate and several bivalent cations on enzyme activity were tested by taking $0.5 \mathrm{~mL}$ aliquots of the enzyme preparation, preincubating them at $37^{\circ} \mathrm{C}$ for $10 \mathrm{~min}$ in absence and presence of the effectors, and then assaying the mixture for enzyme activity. The final concentration of all effectors in the assay medium was $4 \mathrm{mM}$, except for molybdate that was $0.1 \mathrm{M}$ and for galactose, glucose and lactose that were $8 \mathrm{mM}$.

Polyacrylamide gel isoelectric focusing in slab gels was carried out according to Robertson et al. (1987) in the $\mathrm{pH}$ range from 3 to 10 . After isoelectric focusing the gel was separate into two parts, and visualization of protein markers and enzyme bands were carried out according to Simos \& Georgatsos (1988). A pI kit containing markers with pI ranging from 3.55 to 9.30 (Sigma Co.) was used.

\section{Results and Discussion}

A summary of the purification procedure used for the cotyledonary $\beta$-galactosidases isolated from quiescent seeds is presented in table 1 . The initial step $\left(F_{20-60}\right)$ was included to eliminate compounds of small mass and to concentrate the preparation that was then subjected to ion-exchange DEAE-Sephadex followed by affinity on Lactosyl-Sepharose chromatography. The elution pattern of the ion-exchange chromatography showed two peaks of protein and of $\beta$-galactosidase activity (figure 1A): DS-I and DS-II, which were purified 24.2 and 2.4 fold, respectively. The first peak (DS-I), corresponded to the material that was not re- tained by the column, suggesting that the proteins of DS-I are relatively basic in nature. A similar $\beta$-galactosidase has been reported in Vigna radiata seeds (Kundu et al. 1990). The second peak (DS-II), eluted with the equilibrium buffer containing $0.7 \mathrm{M}$ sodium chloride, corresponded to a $\beta$-galactosidase strongly bound to the column. The existence of fractions eluted from similar columns which showed cotyledonary $\beta$-galactosidase activity were also observed <\%-2>in Phaseolus vulgaris (Agrawal \& Bahl 1968), Vigna sinensis (Biswas 1987), and Vigna radiata (Kundu et al. 1990) seeds. However, these $\beta$-galactosidases were not strongly bound to the ion-exchange column. The elution pattern of Lactosyl-Sepharose affinity chromatography of DS-I (figure 1B) showed two peaks of enzyme activity: $\beta$-gal I and $\beta$-gal II, which were purified 4.7 and 508.6 fold, respectively. The first peak ( $\beta$-gal I), corresponded to the fraction that was not retained by the column, and the other peak ( $\beta$-gal II), eluted with the equilibrium buffer containing $100 \mathrm{mM}$ lactose and $0.5 \mathrm{M} \mathrm{NaCl}$, corresponded to the enzyme fraction retained by the column. Lactosyl-Sepharose affinity chromatography columns have been used for plant $\beta$-galactosidases isolation and purification (Simos et al. 1989). According to these authors several $\beta$-galactosidases from different plant species have been studied and all of them are retained by these columns. The high enzyme activity observed for the second peak ( $\beta$-gal II) associated to the fact that it

Table 1. Purification of cotyledonary $\beta$-galactosidases from Pitiúba cowpea, Vigna unguiculata (L.) Walp., quiescent seeds $\left(\mathrm{F}_{20-60}=\right.$ ammonium sulphate precipitation $)$.

\begin{tabular}{lccccr}
\hline Step of purification & $\begin{array}{c}\text { Volume } \\
(\mathrm{mL})\end{array}$ & $\begin{array}{c}\text { Total activity } \\
\left(\mathrm{UA}_{\mathrm{min}}^{-1}\right)\end{array}$ & $\begin{array}{c}\text { Total Protein } \\
(\mathrm{mg})\end{array}$ & $\begin{array}{c}\text { Specific Activity } \\
\left(\mathrm{UA}_{\mathrm{mgP}}{ }^{-1} \cdot \mathrm{min}^{-1}\right)\end{array}$ & $\begin{array}{c}\text { Factor of Purifi- } \\
\text { cation }\end{array}$ \\
\hline Crude Extract & 270.0 & 44,352 & $1,158.0$ & 38 & 1 \\
F20-60 & 53.5 & 42,372 & 219.0 & 194 & 5.1
\end{tabular}

DEAE-Sephadex chromatography8

$\begin{array}{lrrrrrr}\text { DS-I } & 153.0 & 26,020 & 28.3 & 919 & 24.2 & 2.4\end{array}$

Lactosyl-Sepharose affinity chromatography 8

\begin{tabular}{lrrrrr}
$\beta$-gal I & 37.0 & 4,172 & 23.2 & 180 & 4.7 \\
$\beta$-gal II & 32.5 & 9,663 & 0.5 & 19,325 & 508.6 \\
$\beta$-gal III & 40.0 & 5,651 & 2.4 & 2,355 & 62.0 \\
\hline
\end{tabular}


was retained by this type of affinity chromatography column reinforces the idea that $\beta$-gal II corresponds to a $\beta$-galactosidase. Even though $\beta$-gal I has shown a much lower enzyme activity than $\beta$-gal II it can be also considered as a fraction containing $\beta$-galactosidase because the binding to the
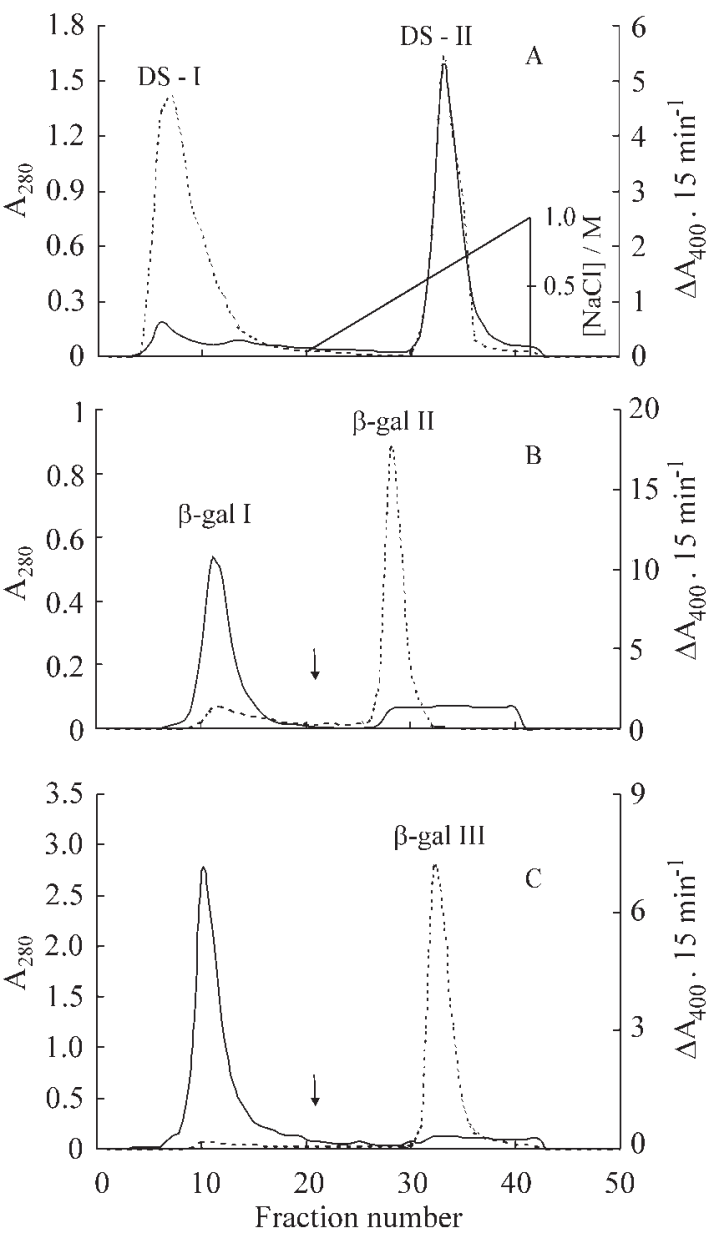

Figure 1. Purification of cotyledonary $\beta$-galactosidases extracted from Pitiúba cowpea, Vigna unguiculata (L.) Walp., quiescent seeds. A. DEAE-Sephadex chromatography of cotyledonary $\beta$-galactosidase rich fraction $\left(F_{20-60}\right)$. B. Lactosyl-Sepharose affinity chromatography of the cotyledonary $\beta$-galctosidase rich peak (DS-I). C. Lactosyl-Sepharose affinity chromatography of the cotyledonary $\beta$-galctosidase rich peak (DS-II). Protein ( $\mathrm{A}_{280}$, $-)$ and $\beta$-galctosidase activity $\left(\Delta \mathrm{A}_{400} \times 15 \mathrm{~min}^{-1},--\right)$. The arrows represent the start of the addtion of the elution buffer containing $100 \mathrm{mM}$ lactose and $0.5 \mathrm{M} \mathrm{NaCl}$ as described under Material and methods.

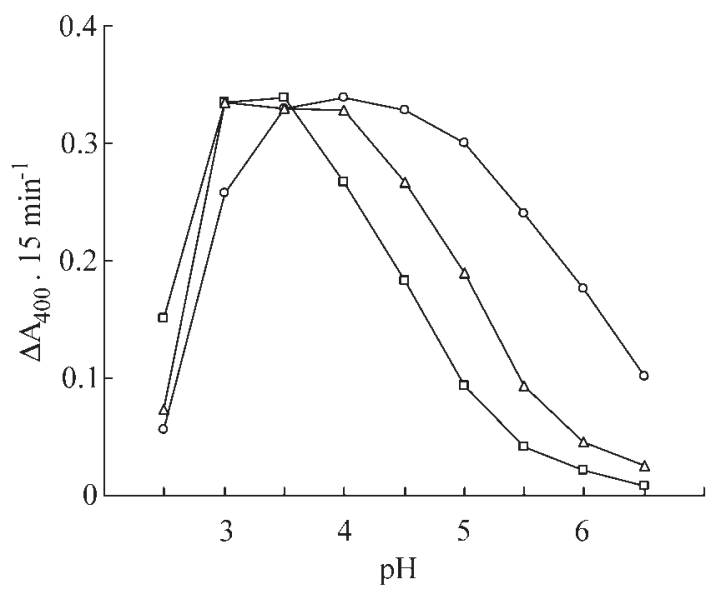

Figure 2. Enzyme activity as a function of the assay medium $\mathrm{pH}$ of partially purified cotyledonary $\beta$-galactosidases extracted from Pitiúba cowpea, Vigna unguiculata (L.) Walp., quiescent seeds. $\beta$-gal I (o), $\beta$-gal II $(\square)$ and $\beta$-gal III ( $\Delta$ ). Values represent the mean of three different experiments with three replicates each.

Lactosyl-Sepharose affinity column is not an absolute criteria for plant $\beta$-galactosidase identification. The elution pattern of Lactosyl-Sepharose affinity chromatography of DS-II (figure 1C) showed only one peak of enzyme activity ( $\beta$-gal III), which was purified 62 fold. This peak, eluted with the equilibrium buffer containing $100 \mathrm{mM}$ lactose and $0.5 \mathrm{M}$ $\mathrm{NaCl}$, probably corresponded to a $\beta$-galactosidase because it showed high enzyme activity and it was bound to the Lactosyl-Sepharose affinity colunm (Simos et al. 1989). Therefore, the cotyledonary extract from quiescent seeds of Pitiúba cowpea contained three fractions showing high $\beta$-galactosidase activity: $\beta$-gal I, $\beta$-gal II, and $\beta$-gal III, which were purified about 5, 509, and 62 fold, respectively (table $1)$.

The effect of $\mathrm{pH}$ on the cotyledonary $\beta$-galactosidases ( $\beta$-gal I, $\beta$-gal II, and $\beta$-gal III) activities is shown in figure 2 . In the $\mathrm{pH}$ range 2.5-6.5 the maximum enzyme activity varied among the three $\beta$-galactosidase rich fractions: $3.5-4.5$ for $\beta$-gal I, 3.0-3.5 for $\beta$-gal II, and 3.0-4.0 for $\beta$-gal III (figure 2). These results are similar to those found for cotyledonary $\beta$-galactosidases from Vigna sinensis (Biswas 1987) and Vigna radiata (Kundu et al. 1990), as well as for seeds (Agrawal \& Bahl 1968, Li et al. 1975, Matheson \& Saini 1977, Edwards et 
Revta brasil. Bot., São Paulo, V.23, n.1, p.69-76, mar. 200073

al. 1988, Sekimata et al. 1989, Giannakouros et al. 1991, Buckeridge \& Reid 1994), shoots (Konno \& Tsumuki 1993), leaves (Sawicka \& Kacperska 1995) and fruits (Pressey 1983, Ogawa et al. 1990, Ranwala et al. 1992) of different species.

The effect of assay temperature on the activities of partially purified $\beta$-galactosidases is shown in figure 3 . In the temperature range studied $\left(30-80{ }^{\circ} \mathrm{C}\right)$ the activities of all $\beta$-galactosidases increased with temperature up to $60{ }^{\circ} \mathrm{C}$ after which they decreased reaching at $80{ }^{\circ} \mathrm{C}$ values that corresponded to approximately $10 \%$ of their maximal activities. Similar temperature optima have been reported for other plant $\beta$-galactosidases (Biswas 1987, Edwards et al. 1988, Kundu et al. 1990, Ogawa et al. 1990, Ranwala et al. 1992, Konno \& Tsumuki 1993, Sawicka \& Kacperska 1995).

The effect of temperature on partially purified cotyledonary $\beta$-galactosidases is shown in figure 4 . The enzymes preincubated at temperature ranging from 30 to $80^{\circ} \mathrm{C}$ for 10 min maintained a quite stable activity up to $50{ }^{\circ} \mathrm{C}$ when there was an abrupt decrease in enzyme activity, and at $70{ }^{\circ} \mathrm{C}$ they were completely inactivated. This rapid decrease in enzyme activity above $50{ }^{\circ} \mathrm{C}$ was observed for all $\beta$-galactosidases studied. These data indicate that the partially purified cotyledonary $\beta$-gal I, $\beta$-gal II

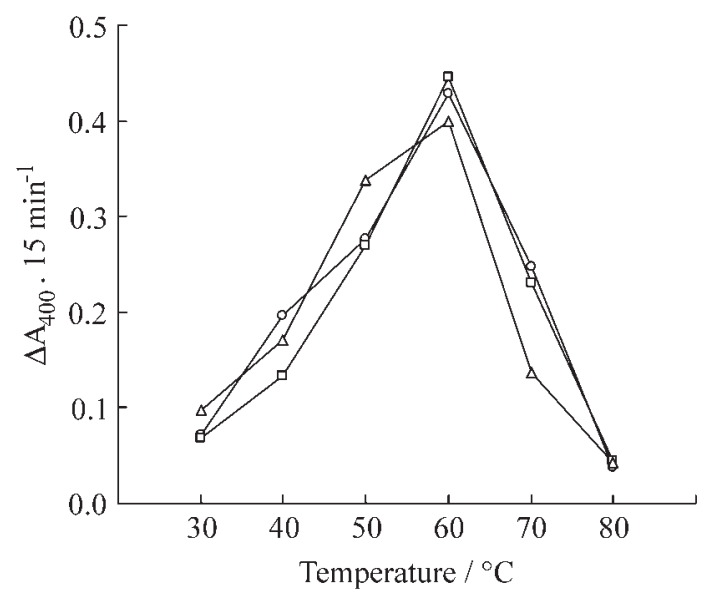

Figure 3. Enzyme activity as a function of assay medium temperature of partially purified cotyledonary $\beta$-galctosidases extracted from Pitiuba cowpea, Vigna unguiculata (L.) Walp., quiescent seeds. $\beta$-gal I (o), $\beta$-gal II $(\square)$ and $\beta$-gal III $(\Delta)$. Values represent the mean of three different experiments with three replicates each. and $\beta$-gal III extracted from Pitiúba cowpea were heat stable up to $50^{\circ} \mathrm{C}$, and that their thermostability is similar to the $\beta$-galactosidases isolated from cotyledons of Vigna sinensis (Biswas 1987) and Vigna radiata (Kundu et al. 1990), as well as from $\beta$-galactosidases isolated from other plants sources (Konno \& Katoh 1986, Simos \& Georgatsos 1988). However, they differ from the ones obtained with $\beta$-galactosidases isolated from radish (Sekimata et al. 1989) and tomato seeds (Pressey 1983), which were inactive at $55^{\circ} \mathrm{C}$ or had only $50 \%$ of their initial activities at temperature ranging from 48 to $52{ }^{\circ} \mathrm{C}$, respectively.

The effects of bivalent cations and other effectors on the activities of the partially purified cotyledonary $\beta$-galactosidases are shown in table 2 . These effects did not vary among the partially purified cotyledonary $\beta$-galactosidases, except for $\mathrm{Mn}^{2+}$ and EDTA, which affected differently $\beta$-gal I, $\beta$-gal II, and $\beta$-gal III. $\mathrm{Mn}^{2+}$ did not affect the activity of $\beta$-gal I, and strongly inhibited the activities of $\beta$-gal II and $\beta$-gal III, while EDTA has shown a weak inhi-

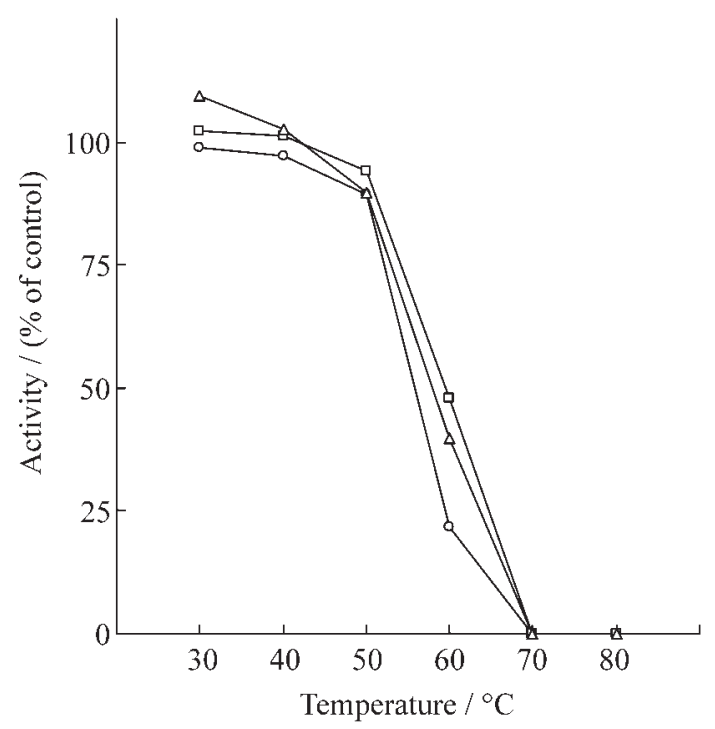

Figure 4. Enzyme thermostability of partially purified cotyledonary $\beta$-galctosidases extracted from Pitiúba cowpea, Vigna unguiculata (L.) Walp., quiescent seeds. $\beta$-gal I (o), $\beta$-gal II ( $\square)$ and $\beta$-gal III $(\Delta)$. Values are expressed as percentage of the control (activity of the enzyme preincubated at ambient temperature for $10 \mathrm{~min}$ ), and represent the mean of three different experiments with three replicates each. 
bition of both $\beta$-gal I and $\beta$-gal II, but strongly inhibited $\beta$-gal III. The analysis of each of the effectors on the activities of the three partially purified cotyledonary $\beta$-galactosidases has shown that while $\mathrm{Mg}^{2+}$, $\mathrm{Ca}^{2+}, \mathrm{Zn}^{2+}, \mathrm{Co}^{2+}$, tartarate, molybdate, glucose, and lactose weakly inhibited their activities (less than $40 \%$ ), the inhibition due to $\mathrm{Cu}^{2+}$ and galactose were strong (higher than 60\%), and $\mathrm{Hg}^{2+}$ completely inhibited the activities of all Pitiúba cowpea partially purified cotyledonary enzymes. Studies concerning the response of plant $\beta$-galactosidases to effectors are scarce, especially those dealing with the effects of glucose, lactose, molybdate and tartarate. Nevertheless, the effects of $\mathrm{Ca}^{2+}, \mathrm{Co}^{2+}, \mathrm{Hg}^{2+}, \mathrm{Mg}^{2+}, \mathrm{Zn}^{2+}$, galactose and glucose on different plant $\beta$-galactosidases were similar to those obtained here (Li et al. 1975, Biswas 1987, Corchete \& Guerra 1987a, Kundu et al. 1990, Ogawa et al. 1990, Konno \& Katoh 1992, Ranwala et al. 1992). However, $\mathrm{Co}^{2+}$, which behaved as a weak inhibitor of the cotyledonary $\beta$-galactosidases from Pitiúba cowpea quiescent seeds, has been described as a strong inhibitor of 4-day-old Vigna sinensis cotyledonary $\beta$-galactosidases (Biswas 1987), and did not affect the activities of cotyledonary $\beta$-galactosidases extracted from 4-day-old Vigna radiata (Kundu et al. 1990). Molybdate, which was a weak inhibitor of the cotyledonary $\beta$-galactosidases studied in this paper, has been described as a strong inhibitor of both 4-day-old Vigna sinensis (Biswas 1987) and Vigna radiata (Kundu et al. 1990) cotyledonary $\beta$-galactosidases. These results suggest that the response of cotyledonary $\beta$-galactosidases is a function of both species differences and developmental stage. The strong inhibition of galactose (table 2), which is one of the products of the catalytic action of $\beta$-galactosidases on $\beta$-galactosides has also been observed by others ( $\mathrm{Li}$ et al. 1975, Biswas 1987, Corchete \& Guerra 1987a, Kundu et al. 1990). These results suggest that galactose might be acting as an end product inhibitor of $\beta$-galactosidases.

Isoelectric focusing in polyacrylamide slab gels was performed with the partially purified cotyledonary $\beta$-galactosidases ( $\beta$-gal I, $\beta$-gal II and $\beta$-gal III).

Table 2. Effect of bivalent cations and other effectors on the activity of partially purified cotyledonary $\beta$-galactosidases from Pitiúba cowpea, Vigna unguiculata (L.) Walp., quiescent seeds. The values are expressed in percentage of the control (without the addition of effectors); they represent the mean (standard deviation of three different experiments with three replicates each.

\begin{tabular}{|c|c|c|c|c|}
\hline \multirow[t]{2}{*}{ Addition } & \multirow{2}{*}{$\begin{array}{l}\text { Final concentration } \\
\qquad(\mathrm{mM})\end{array}$} & \multicolumn{3}{|c|}{ Activity (\% of control) } \\
\hline & & $\beta$-gal I8 & $\beta$-gal II8 & $\beta$-gal III8 \\
\hline $\mathrm{MnCl}_{2}$ & 4.0 & $109(7.2$ & $38(9.3$ & $3(0.6$ \\
\hline $\mathrm{MgCl}_{2}$ & 4.0 & $94(3.2$ & $104(9.0$ & $81 / 8.2$ \\
\hline $\mathrm{CaCl}_{2}$ & 4.0 & $92(2.0$ & $93(11.5$ & $74(2.0$ \\
\hline $\mathrm{ZnCl}_{2}$ & 4.0 & $78 / 4.9$ & $80(3.6$ & $86(7.0$ \\
\hline $\mathrm{CoCl}_{2}$ & 4.0 & $73(4.5$ & $82(9.8$ & $71(3.2$ \\
\hline $\mathrm{CuCl}_{2}$ & 4.0 & 41 ( 3.5 & $5(2.6$ & $18 / 2.5$ \\
\hline $\mathrm{HgCl}_{2}$ & 4.0 & 0 & 0 & 0 \\
\hline Tartarate & 4.0 & $73(5.5$ & $63 / 12.3$ & $65 / 10.3$ \\
\hline Molybdate & 0.1 & $64(6.0$ & $60(8.9$ & $67(2.5$ \\
\hline EDTA & 4.0 & $78 / 3.2$ & $76(11.8$ & $3(1.2$ \\
\hline Galactose & 8.0 & $35(7.5$ & $12(1.5$ & $21(2.1$ \\
\hline Glicose & 8.0 & $85(3.2$ & $76(6.1$ & $72(6.2$ \\
\hline Lactose & 8.0 & $73(6.1$ & $70(2.0$ & $60(11.0$ \\
\hline
\end{tabular}


Revta brasil. Bot., São Paulo, V.23, n.1, p.69-76, mar. 200075

Both $\beta$-gal I and $\beta$-gal III showed only one band of enzyme activity corresponding to pIs 8.7 and 6.6, while $\beta$-gal II showed two distinct bands of enzyme activity corresponding to pIs 8.4 and 8.1 (data not shown). Although the results of Lacosyl-Sepharose affinity chromatography (figure $1 \mathrm{~B}$ and $1 \mathrm{C}$ ) suggest the existence of three isoforms of cotyledonary $\beta$-galactosidases ( $\beta$-gal I, $\beta$-gal II and $\beta$-gal III), isoelectric focusing in polyacrylamide slab gel of these proteins (data not shown) indicated that the quiescent seeds of this cultivar of Vigna unguiculata possess four isoforms of cotyledonary $\beta$-galactosidases. The presence of four isoforms of cotyledonary $\beta$-galactosidases has also been observed in 4-day-old seedlings of Vigna sinensis (Biswas 1987) and Vigna radiata (Kundu et al. 1990), using different methods of enzyme purification. The presence of multiple forms of the same enzyme in cotyledons suggest that the isoforms might have different metabolic roles in different tissues or cells. Therefore, their location within the cotyledons as well as their changes along germination and seedling establishment should be a prerequisite for the determination of their biochemical and physiological roles, at least during this developmental process.

Acknowledgements - To Financiadora de Estudos e Projetos (FINEP) and Conselho Nacional de Desenvolvimento Científico e Tecnológico $(\mathrm{CNPq})$ for their financial support.

\section{References}

AGRAWAL, K.M.L. \& BAHL, O.P. 1968. Glycosidases of Phaseolus vulgaris. II. Isolation and general properties. The Journal of Biological Chemistry 243:103-111.

ALI, Z.M., ARMUGAM, S. \& LAZAN, H. 1995. $\beta$-Galactosidase and its significance in ripening mango fruit. Phytochemistry 38:1109-1114.

BISWAS, T.K. 1986. Cationic form of $\beta$-galactosidase in the germinating seeds of Vigna sinensis (Linn) Savi. Archives of Biochemistry and Biophysics 251:379-384.

BISWAS, T.K. 1987. Characterization of $\beta$-galactosidases from the germinating seeds of Vigna sinensis. Phytochemistry 26:359-364.
BRADFORD, M.M. 1976. A rapid and sensitive method for the quantitation of microgram quantities of protein utilizing the principle of protein-dye binding. Analytical Biochemistry 72:248-254.

BUCKERIDGE, M.S. \& REID, J.S.G. 1994. Purification and properties of a novel $\beta$-galactosidase or exo-(1-4)- $\beta$-D-galactanase from the cotyledons of germinated Lupinus angustifolius L. seeds. Planta 192:502-511.

CAMPILlO, E.D. \& SHANNON, L.M. 1982. An $\alpha$-galactosidase with hemagglutinin properties from soybean seeds. Plant Physiology 69:628-631.

CORCHETE, M.P. \& GUERRA, H. 1986. Effect of $\mathrm{NaCl}$ and polyethylene glycol on solute content and glycosidase activities during germination of lentil seeds. Plant Cell and Environment 9:589-593.

CORCHETE, M.P. \& GUERRA, H. 1987a. $\alpha$ - and $\beta$-galactosidase activities in proteins bodies and cell walls of lentil seed cotyledons. Phytochemistry 26:927-932.

CORCHETE, M.P. \& GUERRA, H. 1987b. $\alpha$ - and $\beta$-galactosidase activities during germination of lentil seeds. Plant Physiology and Biochemistry 25:105-109.

DEY, P.M. 1984. Occurrence of glycoprotein glycosidases in mature seeds of mung bean (Vigna radiata). Phytochemistry 23:257-260.

DOPICO, B., NICOLÁS, G. \& LABRADOR, E. 1989. Partial purification of cell wall $\beta$-galactosidases from Cicer arietinum epicotyls. Relationship with cell wall autolytic processes. Physiologia Plantarum 75:458-464

EDWARDS, M., BOWMAN, Y.J.L., DEA, I.C.M. \& REID, J.S.G. 1988. A $\beta$-galactosidase from nasturtium (Tropaeolum majus L.) cotyledons. The Journal of Biological Chemistry 263:4333-4337.

ENÉAS-FILHO, J., OLIVEIRA-NETO, O.B., PRISCO, J.T., GOMES-FILHO, E. \& NOGUEIRA, C.M. 1995. Effects of salinity in vivo and in vitro on cotyledonary galactosidases from Vigna unguiculata (L.) Walp. during seed germination and seedling establishment. Revista Brasileira de Fisiologia Vegetal 7:135-142.

GIANNAKOUROS, T, KARAGIORGOS, A. \& SIMOS, G. 1991. Expression of $\beta$-galactosidase multiple forms during barley (Hordeum vulgare) seed germination. Separation and characterization of enzyme isoforms. Physiologia Plantarum 82:413-418. 
76J. Enéas-Filho et al.: $\beta$-galactosidases from Vigna unguiculata seeds

GÓMEZ, L.D., CASANO, L.M., BRAGA, M.R. \& BUCKERIDGE, M.S. 1995. Changes in extracellular $\beta$-galactosidase and protease activities during bean hypocotyl growth. Revista Brasileira de Fisiologia Vegetal 7:1-6.

KANFER, J.N., PETROVICH, R. \& MUMFORD, R.A. 1973. Purification of $\alpha$ - and $\beta$-galactosidases by affinity chromatography. Analytical Biochemistry 55:301-305.

KITAGAWA, Y., KANAYAMA, Y. \& YAMAKI, S. 1995. Isolation of $\beta$-galactosidase fractions from japanese pear: Activity against native cell wall polysaccharides. Physiologia Plantarum 93:545-550.

KONNO, H. \& KATOH, K. 1992. An extracellular $\beta$-galactosidase secreted from cell suspension cultures of carrot. Its purification and involvement in cell wall-polysaccharide hydrolysis. Physiologia Plantarum 85:507-514.

KONNO, H. \& TSUMUKI, H. 1993. Purification of a $\beta$-galactosidase from rice shoots and its involvement in hydrolysis of the natural substrate in cell walls. Physiologia Plantarum 89: 40-47.

KUNDU, R.K., DE-KUNDU, P. \& BANERJEE, A.C. 1990. Multiple forms $\beta$-galactosidase from the germinating seeds of Vigna radiata. Phytochemistry 29:2079-2082.

LI, S-C., MAZZOTTA, M.Y., CHIEN, S-F. \& LI, Y-T. 1975. Isolation and characterization of jack bean $\beta$-galactosidase. The Journal of Biological Chemistry 250:6786-6791.

McILVAINE, T.C. 1921. A buffer solution for colorimetric comparison. The Journal Biological Chemistry 49:185-186.

MATHESON, N.K. \& SAINI, H.S. 1977. $\alpha$-L-Arabinofuranosidases and $\beta$-D-galactosidases in germinating-lupin cotyledons. Carbohydrate Research 57:103-116.
OGAWA, H., FUKUMOTO, H., YANO, T., YAMAMOTO, K. \& TOCHIKURA, T. 1990. Purification and characterization of $\beta$-galactosidase from kiwifruit. Nippon Shokuhin Kogyo Gakkaishi 37:298-305.

PRESSEY, R. 1983. $\beta$-Galactosidases in ripening tomatoes. Plant Physiology 71:132-135.

RANWALA, A.P., SUEMATSU, C. \& MASUDA, H. 1992. The role of $\beta$-galactosidase in the modification of cell wall components during muskmelon fruit ripening. Plant Physiology 100:1318-1325.

ROBERTSON, E.F., DANNELLY, H.K., MALLOY, P.J. \& REEVES, H. 1987. Rapid isoelectric focusing in a vertical polyacrylamide minigel system. Analytical Biochemistry 167: 290-294.

SAWICKA, T. \& KACPERSKA, A. 1995. Soluble and cell wall-associated $\beta$-galactosidases from cold-grown rape (Brassica napus L., var. oleifera L.) leaves. Journal of Plant Physiology 145:357-362.

SEKIMATA, M., OGURA, K., TSUMURAYA, Y. HASHIMOTO, Y. \& YAMAMOTO, S. 1989. A $\beta$-galactosidase from radish (Raphanus sativus L.) seeds. Plant Physiology 90:567-574.

SIMOS, G. \& GEORGATSOS, J.G. 1988. Lactose-hydrolyzing $\beta$-glycosidases of barley meal. Biochimica et Biophysica Acta 967:17-24.

SIMOS, G., GIANNAKOUROS, T. \& GEORGATSOS, J.G. 1989. Plant $\beta$-galactosidases: purification by affinity chromatography and properties. Phytochemistry 28:2587-2592.

VEAU, E.J.I.D., GROSS, K.C., HUBER, D.J. \& WATADA, A.E. 1993. Degradation and solubilization of pectin by $\beta$-galactosidases purified from avocado mesocarp. Physiologia Plantarum 87:279-285.

WALLENFELS, K. \& MALHOTRA, O.M. 1961. Galactosidases. Advances in Carbohydrate Chemistry 16:239-298. 